\title{
Corpus
}

Archivos virtuales de la alteridad americana

Vol 3, No 2 | 2013

Julio / Diciembre 2013

\section{La "nación católica" y la historia argentina contemporánea}

\section{Miranda Lida}

\section{(2) OpenEdition}

\section{Journals}

Edición electrónica

URL: http://journals.openedition.org/corpusarchivos/579

DOI: 10.4000/corpusarchivos.579

ISSN: 1853-8037

\section{Editor}

Diego Escolar

\section{Referencia electrónica}

Miranda Lida, «La "nación católica" y la historia argentina contemporánea », Corpus [En línea], Vol 3, No 2 | 2013, Publicado el 20 diciembre 2013, consultado el 30 abril 2019. URL : http:// journals.openedition.org/corpusarchivos/579; DOI : 10.4000/corpusarchivos.579

Este documento fue generado automáticamente el 30 abril 2019. 


\title{
La "nación católica" y la historia argentina contemporánea
}

\author{
Miranda Lida
}

\section{NOTA DEL EDITOR}

Fecha de recepción del original: 01/12/2013

Fecha de aceptación para publicación: 07/12/2013

1 1. Es difícil hablar de la religión en la Argentina contemporánea sin hacer referencia al "mito de la nación católica" (Zanatta, 1996). Tuvo tanta fuerza esta matriz interpretativa, que Loris Zanatta elaboró para pensar la década de 1930, que no faltan estudios que refieren a sus orígenes, remontándonos en el tiempo hacia atrás, así como también a sus derivaciones y consecuencias, orientándonos hacia adelante. La concepción esencialista y ahistórica de la nación que dicho mito postula tiene un poderoso potencial explicativo cuando se estudia el catolicismo en relación con las ideologías y la historia política contemporánea, en especial en el período que comprende desde 1930 a 1983. Las transformaciones sociales, políticas y también religiosas que tuvieron lugar luego de esta última fecha tornan difícil, incluso en más de un sentido inoperante, el recurso a esa sola matriz para explicar el papel de la religión en la Argentina de hoy. Pero ello no le resta capacidad explicativa de todas formas, en especial si uno desea entender la fuerte relación que la Argentina tiene con el catolicismo, tal como puso en evidencia la reciente designación de Jorge Mario Bergoglio como papa. El primer papa de origen extraeuropeo fue de nacionalidad argentina, al igual que el primer Congreso Eucarístico Internacional celebrado en América Latina.

2 2. El punto de partida de la identificación de la nación con el catolicismo es difícil de datar con precisión, pero en tal caso está claro que este discurso cobró cierta presencia en las vísperas del Centenario, para luego expandirse como un rayo en toda la cultura católica de entreguerras. Era un discurso militante, aguerrido, que combinaba la defensa de los 
valores religiosos con un tono de cruzada que podía tornarse virulento, puesto que identificaba a su vez sus enemigos en el liberalismo y las ideologías de izquierda, a las que había que combatir. Esta cruzada se libraba a través de distintas vías: la interpelación al Estado para que reconociera la enseñanza religiosa obligatoria; la aspiración a convertir a todos sus fieles en adalides del catolicismo integral, que hicieran regir plenamente sus vidas por valores católicos, en todos sus aspectos; la pretensión de moralizar la sociedad a través de su influencia en las costumbres, los medios de comunicación y la cultura de masas, cuyo laicismo se deploraba, así como también su apartamiento de los valores ajenos al catolicismo. Así, el discurso de cruzada se volvía fácilmente intolerante, puesto que todo aquello que no se condecía con él se volvía inasimilable, un "otro" ajeno, incluso amenazador. Su demonización no faltó en el discurso católico, incluso en la propaganda más militante. Cristo Rey no admitía medias tintas.

El mito de la nación católica, que fue tan útil para amalgamar a las Fuerzas Armadas y a la Iglesia, según refiere Zanatta, excedió el ámbito puramente militarista. El mito se difundió en amplios sectores de la sociedad argentina, mucho más allá de los puramente castrenses, gracias a la vasta llegada que el catolicismo alcanzó en los medios de comunicación y las industrias culturales de la época: editoriales de masas, radio, prensa escrita. El catolicismo contó con fuerte presencia en las emisoras de radio más importantes de la época, gracias a Dionisio Napal (orador estrella de Radio Belgrano) y Gustavo Franceschi (en Radio Splendid), entre otras voces de fuerte resonancia. A ello le sumamos el diario "El Pueblo", portavoz de un exacerbado discurso de cruzada que tiñó también con su influencia a la prensa católica de menor envergadura (revistas parroquiales y boletines oficiales en general) (Lida, 2012). Era muy difícil escapar a un discurso que se volvía monocorde, asfixiante, imponiéndole a la cultura católica del período un aspecto que pretendía volverse homogéneo, sin matices. No obstante los había de todas formas, aunque quizás no eran fáciles de advertir a simple vista. Algunas veces se volvían voces aisladas en el seno del catolicismo de su época, como las que se canalizaron a través de la revista "Orden Cristiano"; otras en cambio se dejaban ver a trasluz incluso en el seno de la propia Iglesia, como pone en evidencia la figura de Monseñor De Andrea, de un integrismo tibio, que se aparta de la intolerancia visceral y que se confunde con un difuso "catolicismo liberal" (Zanca, 2013; Lida, 2013).

Sin embargo, el discurso católico integrista fue el que mejor llegada masiva tuvo en los años treinta. Inesperadamente, alcanzó masividad y algún atisbo de popularidad, como demuestra la saga de obras que el padre Virgilio Filippo, furibunda pluma católica de época, hizo publicar en la masiva editorial Tor. Este tipo de retórica entroncó con una amplia gama de fenómenos que hacen a la vida cotidiana en cualquier ciudad moderna, que van desde el tiempo de ocio, al turismo, los medios masivos de comunicación, el consumo, los deportes de masas, las transformaciones urbanas y -no menos importantelas formas de hacer política propias de una sociedad moderna y de masas, formas que el catolicismo supo hacer suyas desde muy temprano en el siglo XX, tanto a través de su uso del espacio público como de la transmisión de un discurso político que aspiraba a mostrarse lo más compacto y homogéneo posible, tal como se advierte a través de sus formas de organización militante, su presencia creciente en las calles en abierta conflagración, aunque sólo fuere retórica, con sus rivales ubicados por fuera del campo católico. Aquí reside una de las cuestiones que más han sido estudiadas en relación con la historia del catolicismo argentino: su estrecha relación con la política en tiempos de repliegue de la democracia. 
5 3. La salida de la Segunda Guerra Mundial puso a prueba el mundo que la precedió. En 1944, el papa Pío XII se pronunció favorablemente acerca de la democracia en una alocución de Navidad que tuvo gran repercusión en ámbitos católicos, si bien fue juzgada demasiado tibia en más de una ocasión. En la Argentina, ello implicaría que el catolicismo de tono triunfal, forjado en los años treinta a la luz de los congresos eucarísticos, debió dejar a un lado su retórica más militante. De todas formas, era evidente que con esa sola retórica ya no bastaría para aunar a las fuerzas católicas en un movimiento sólidamente amalgamado. Desde fines de los años treinta, se desarrollaron movimientos católicos juveniles (la JOC; la JAC, rama masculina de la Acción Católica y las Vanguardias Obreras Católicas, de los Círculos de Obreros) que adquirieron su propio dinamismo, en ocasiones incluso con notable independencia con respecto de la jerarquía (Caimari, 1994; Lida, 2005; Lida, 2010). El activismo de estos grupos puso a prueba la solemnidad y rigidez de las jerarquías eclesiásticas, e hizo posible que muchos de sus miembros se sintieran atraídos por el peronismo, al menos en sus primeros tiempos. La idea de un catolicismo compacto, unificado, homogéneo hacía agua. ¿Cómo podría pues seguir aspirando a identificarse con la nación toda?

6 Las voces que desafiaron el mito de la nación católica fueron muchas, pero en tal caso lo que importa destacar es que fueron mucho más certeros y contundentes los golpes que aquel recibió desde dentro del propio universo católico, que los que provinieron de factores exógenos tales como las ideologías laicas o de izquierda o cualquier tipo de medidas emprendidas a través del Estado por sucesivos gobiernos de turno. No era necesario aguardar a lo más violento de la colisión entre Perón y la Iglesia, de 1954-55 para advertir que se estaban produciendo sutiles transformaciones en un universo católico que bien hubiera deseado permanecer igual a sí mismo. En sus últimos años de vida, Gustavo Franceschi bregó para que el catolicismo argentino tomara conciencia del ritmo imparable de la modernización, al que no cabía ya oponerle ningún tipo de prédica integrista: "¿la Iglesia se moderniza? Sacerdotes obreros; religiosas sin hábito; misas vespertinas; modificación de los ayunos... ¿Qué hay en el fondo de todo esto?", fue el tema que escogió en 1953 para una de sus tantas conferencias sobre temas de actualidad. ${ }^{1} \mathrm{La}$ solemnidad de los treinta, propia de un catolicismo que tenía mucho de victoriano, se disolvió de un plumazo. Director de Criterio desde 1932, Franceschi sabía leer los cambios que se daban en la sociedad, e incluso trataba de adelantarse a ellos en la medida de lo posible.

7 La crisis desatada con el gobierno de Perón aceleró los tiempos, pero de ninguna manera decidió el rumbo de las transformaciones por venir, ya en marcha de todas formas; en pocas palabras, sirvió de poderoso catalizador, sin ser más que eso, un fermento de procesos ya desencadenados desde tiempo atrás. Una vez caído Perón, la Iglesia ni siquiera presionó para intentar recomponer el orden anterior. La educación no volvió a las escuelas públicas, mientras que el uso del clergymen se volvía un dato irrefrenable de la realidad. La decoración señorial de las iglesias incendiadas en la infausta noche del 16 de junio de 1955 no fue reconstruida en el mismo estilo después del saqueo, salvo escasas excepciones; se prefirió más bien la sobriedad y sencillez que cobrarían todavía tanta más visibilidad luego del Concilio Vaticano II. Tanto es así que ya para la década de 1950 pueden advertirse cambios que habrán de signar los años por venir: así, la popularización de los campamentos juveniles de verano, las misiones rurales o en villas miseria, las peñas folklóricas desarrolladas en sedes parroquiales, entre otras novedades que tendrían vasta expansión en los años sesenta (Lida, 2012). Acierta José Zanca cuando percibe que la 
década de 1950 es clave para comprender los cambios por venir en el catolicismo argentino, puesto que anticiparon algunas de las transformaciones que suelen ser adscriptas al contexto conciliar (Zanca, 2006).

El desarrollismo, muy en boga luego de la Revolución Libertadora en los más vastos sectores sociales y políticos gracias a su volatilidad, impregnó también al catolicismo de la época. Como nunca antes, la Iglesia comenzó a acercarse a ranchos, villas miseria, pueblos de frontera y, en pocas palabras, a la Argentina "profunda" que era ignorada por las clases medias de las grandes ciudades: las nuevas diócesis creadas luego de la caída de Perón en las provincias más "subdesarrolladas" del país fueron un neto producto de este cambio de sensibilidad. Vinieron a darle un nuevo aspecto al catolicismo, que recobraba así su poder de atracción, gracias a lo que podríamos denominar una sensibilidad antiburguesa que -desarrollismo mediante- se desplegaría a través de todas esas nuevas prácticas que el catolicismo puso en acción a fin de atraer a los jóvenes, a la par que los alejaba del consumo estandarizado propio de la gran ciudad, y todo lo que esto implicaba. De este modo se fue delineando un estilo de Iglesia Católica en el que pasaron a prevalecer rasgos cada vez más llanos, menos solemnes; en lugar de vistosos ornamentos sagrados y lujosos atuendos, comenzó a reclamarse una mayor sencillez y austeridad en el culto. La "Misa Criolla" fue en los años sesenta su expresión más elocuente.

Todo ello terminó de un modo u otro por provocar una profunda modificación en la imagen tradicional de la Iglesia, solemne, ceremoniosa y rígida hasta no mucho tiempo atrás. Los cambios quedaron condensados en todas las novedades que trajo consigo el Concilio Vaticano II que, en plena década de 1960, vino a aggiornar las facetas más anquilosadas de la institución, al menos a primera vista. Y con ello se le abrió el paso a que arraigaran nuevas ideas tanto teológicas cuanto políticas, así como también a que se apelara a estrategias cada vez más innovadoras para atraer al público y, en especial, a los jóvenes, que se acercaron con entusiasmo a un catolicismo que, a fuerza de campamentos, misiones populares y otras tantas actividades parroquiales que desafiaban el tono homogéneo y estandarizado de la sociedad de consumo y de la televisión, lograría un éxito sin precedentes entre la juventud. Los jóvenes, en efecto, se acercaron al catolicismo y arrastraron consigo todo su ímpetu: las canciones de rock y de folklore, las nuevas modas de los años sesenta y también la política, que venía dada por añadidura. El saldo de ello fue la creciente politización de los más variados ámbitos católicos, y su tendencia a confundirse, por momentos, con la radicalización revolucionaria propia de los años finales de la década de 1960: el muy popular Movimiento de Sacerdotes del Tercer Mundo, de estrechos vínculos con los Montoneros, fue su expresión más elocuente (Martín, 1992; Touris, 2008).

10 Fue imposible que la Iglesia Católica permaneciera a resguardo de las convulsiones de la agitada década de 1970; no pudo permanecer al margen del estallido de la violencia política, de la que no quedó exenta, así como tampoco lo hizo casi ningún otro actor de la sociedad argentina. Tanto es así que las principales organizaciones armadas de los años setenta, el ERP y los Montoneros, tuvieron al catolicismo como uno de sus interlocutores, incluso en sus momentos más difíciles; en 1976, cuando la represión militar arreciaba, ambas agrupaciones dirigieron sendas cartas abiertas al clero argentino, con la expectativa de que éste alzara enérgicamente su voz a fin de lograr poner un freno a la represión. La imagen de la Iglesia como cómplice de la dictadura, que tanta fuerza adquirirá en los años que siguieron a 1983, no era para nada nítida, al menos en principio (Fabris, 2011). Y si bien en los tiempos de la dictadura se habló de un cierto renacimiento 
religioso, que se hacía eco del creciente público que asistió a las peregrinaciones a pie a Luján, entre otras, lo cierto es que el tono de cruzada, tan caro al integrismo heredado de los años treinta, tampoco se hizo oír en el remozado, si bien frágil, catolicismo de masas de los años "de plomo".

Sobre estas bases, la adaptación -luego- a la vida en democracia no resultaría tan traumática para la Iglesia Católica, a pesar de todos los cambios que la década de los ochenta traería consigo en la sociedad, la cultura y la política. Con toda su carga regeneradora, la democracia no llegó a despertar hondas reticencias ni desconfianzas generalizadas en el seno del catolicismo, no obstante lo poderoso de su pasada tradición integrista a lo largo del siglo XX. Luego de 1984 y, más aún, luego de los levantamientos militares que jalonaron la presidencia de Alfonsín, prácticamente no hubo en el clero voces que osaran poner en duda el consenso democrático. Las pocas que pudo haber habido no alcanzaron eco favorable en la sociedad; por el contrario, fueron hondamente repudiadas. De este modo, pues, el consenso en torno a la democracia se afianzó.

4. Ello no significa de todas maneras que "el mito de la nación católica" haya desaparecido por completo del universo de sentido del catolicismo argentino, ya en pleno siglo XXI. Sin embargo, en el transcurso de casi tres cuartos de siglo, desde los años treinta hasta la actualidad, es evidente que ha sufrido un fuerte descentramiento: de haber pretendido ocupar un lugar hegemónico en el seno del catolicismo argentino y, por extensión, en las lecturas acerca de la identidad nacional que circulaban en los años treinta, pasó a tener un lugar secundario, e incluso en coyunturas clave de la historia reciente ha tenido que disputar terreno frente a otras tendencias renovadoras que cobraron especial ímpetu luego del Concilio Vaticano II. Mientras tanto, la propia complejización de la sociedad argentina, el crecimiento del pluralismo en sentido amplio (incluido el religioso), hacen todavía más difícil cualquier aspiración a revivificar aquel mito; hoy en día tal aspiración no podría sino pasar por una añoranza trasnochada, de unos pocos que pretenden hacer revivir el espíritu de cruzada, algo anacrónico, por cierto, en el siglo XXI (Lida y Fabris, 2013).

13 Sin embargo, no deja de ser digno de mención el hecho de que tanto el progresivo abandono del mito de la nación católica como las tendencias reformistas que hoy parecen advertirse en la Iglesia Católica de la mano de Francisco se nutran de tendencias intrínsecas a la propia institución que, atenta a los cambios de época, apuesta por "cambiar para que todo siga igual", según la célebre fórmula de Giuseppe Tomasi Di Lampedusa en su novela Il Gattopardo.

\section{BIBLIOGRAFÍA}

Caimari, L. (1994). Perón y la Iglesia católica. Religión, Estado y sociedad en la Argentina 1943-1955. Buenos Aires: Ariel.

Fabris, M. (2011). La Conferencia Episcopal en tiempos de retorno democrático, 1983-1989. La participación política del actor eclesiástico. Tesis doctoral. Universidad Nacional de Mar del Plata. 
Lida, M. (2005). Catolicismo y peronismo: debates, problemas, preguntas. Boletín del Instituto de Historia Argentina y Americana Dr. Emilio Ravignani, 27, 139-148

Lida, M. (2010). Catolicismo y peronismo: la zona gris. Boletín Ecos de la Historia, Universidad Católica Argentina, 6.

Lida, M. (2012). La rotativa de Dios. Prensa católica y sociedad: El Pueblo 1900-1960. Buenos Aires: Biblos.

Lida, M. (2012b). Catolicismo y sensibilidad antiburguesa. La Iglesia Católica en una era de desarrollo, 1955-65. Quinto Sol, 16: 2.

Lida, M. (2013). Monseñor Miguel De Andrea. Obispo y hombre de mundo. Buenos Aires: Edhasa.

Lida, M. y Fabris, M. (2013). Argentina and the Pope of the End of the World: Antecedents and Consequences. Journal of Latin American Cultural Studies, 22:2, 113-121.

Martín, J.P. (1992). El Movimiento de Sacerdotes para el Tercer Mundo. Un debate argentino. Buenos Aires: Guadalupe

Touris, C. (2008). Sociabilidad e identidad político-religiosa de los grupos católicos tercermundistas en la Argentina (1966-1976). En Moreyra, B. y Mallo, S. (Comps.), Miradas sobre la historia social argentina en los comienzos del siglo XXI. (pp.763-783) Córdoba: Centro de Estudios Históricos Segretti.

Zanatta, L. (1996). Del Estado liberal a la nación católica. Iglesia y Ejército en los orígenes del peronismo. Buenos Aires: UNQ.

Zanca, J. (2006). Los intelectuales católicos y el fin de la cristiandad 1955-1966. Buenos Aires: Fondo de Cultura Económica.

Zanca, J. (2013). Cristianos antifascistas. Conflictos en la cultura católica argentina. Buenos Aires: Siglo XXI.

\section{NOTAS}

1. "Aviso", El Pueblo, 23 de abril de 1953, p. 4.

\section{AUTOR}

\section{MIRANDA LIDA}

CONICET (Consejo Nacional de Investigaciones Científicas y Técnicas) - Universidad Católica Argentina/ Universidad Torcuato Di Tella, Argentina.

Correo electrónico: mlida@uca.edu.ar 